\title{
Temperature variability at Dürres Maar, Germany during the Migration Period and at High Medieval Times, inferred from stable carbon isotopes of Sphagnum cellulose
}

\author{
R. Moschen ${ }^{1}$, N. Kühl ${ }^{2}$, S. Peters ${ }^{3}$, H. Vos $^{4}$, and A. Lücke ${ }^{1}$ \\ ${ }^{1}$ Institute of Bio- and Geosciences: Agrosphere (IBG-3), Research Centre Juelich (Forschungszentrum Jülich), \\ 52425 Juelich, Germany \\ ${ }^{2}$ Steinmann Institute of Geology, Mineralogy and Paleontology, University of Bonn, 53115 Bonn, Germany \\ ${ }^{3}$ Institute of Geology, University of Cologne (Universität zu Köln), 50923 Koeln, Germany \\ ${ }^{4}$ Institute of Energy and Climate Science: Stratosphere (IEK-7), Research Centre Juelich (Forschungszentrum Jülich), \\ 52425 Juelich, Germany
}

Received: 4 February 2011 - Published in Clim. Past Discuss.: 16 February 2011

Revised: 18 August 2011 - Accepted: 23 August 2011 - Published: 27 September 2011

\begin{abstract}
This paper presents a high resolution reconstruction of local growing season temperature (GST) anomalies at Dürres Maar, Germany, spanning the last two millennia. The GST anomalies were derived from a stable carbon isotope time series of cellulose chemically extracted from Sphagnum leaves $\left(\delta^{13} \mathrm{C}_{\text {cellulose }}\right)$ separated from a kettle-hole peat deposit of several metres thickness. The temperature reconstruction is based on the Sphagnum $\delta^{13} \mathrm{C}_{\text {cellulose }} /$ temperature dependency observed in calibration studies. Reconstructed GST anomalies show considerable centennial and decadal scale variability. A cold and presumably wet phase with below-average temperature is reconstructed between the 4th and 7th century $\mathrm{AD}$ which is in accordance with the so called European Migration Period, marking the transition from the Late Roman Period to the Early Middle Ages. At High Medieval Times, the amplitude in the reconstructed temperature variability is most likely overestimated; nevertheless, above-average temperatures are obvious during this time span, which are followed by a temperature decrease. On the contrary, a pronounced Late Roman Climate Optimum, often described as similarly warm or even warmer as medieval times, could not be detected. The temperature signal of the Little Ice Age (LIA) is not preserved in Dürres Maar due to considerable peat cutting that takes place in the first half of the 19th century. The local GST anomalies show
\end{abstract}

Correspondence to: $\mathrm{R}$. Moschen (r.moschen@fz-juelich.de) a remarkable agreement to northern hemispheric temperature reconstructions based on tree-ring datasets and are also in accordance with climate reconstructions on the basis of lake sediments, glacier advances and retreats, and historical datasets. Most notably, e.g., during the Early Middle Ages and at High Medieval Times, temperatures were neither low nor high in general. Rather high frequency temperature variability with multiple narrow intervals of below- and aboveaverage temperatures at maximum lasting a few decades are reconstructed. Especially the agreements between our estimated GST anomalies and temperature reconstructions derived from tree-ring chronologies indicate the great potential of Sphagnum $\delta^{13} \mathrm{C}_{\text {cellulose }}$ time series from peat deposits for palaeoclimate research. This is particularly the case, given that a quantitative $\delta^{13} \mathrm{C}_{\text {cellulose/temperature relationship has }}$ been found for several Sphagnum species. Although the time resolution of Sphagnum $\delta^{13} \mathrm{C}_{\text {cellulose }}$ datasets certainly wouldn't reach the annual resolution of tree-ring data, reconstructions of past temperature variability on the basis of this proxy hold one particular advantage: often due to relatively high peat accumulation rates, especially in kettle-hole bogs accumulated on temperate latitudes over periods of up to several millennia, they allow extending temperature reconstructions based on tree-ring series into the past to enhance our knowledge of natural climate variability during the Holocene.

Published by Copernicus Publications on behalf of the European Geosciences Union. 


\section{Introduction}

Currently, there is specific interest in climate change during our historical past and in the human impact on past and future climate and ecosystem dynamics (e.g., Esper et al., 2005; Wanner et al., 2008). In this context, the reconstruction of decadal to centennial scale natural climate variability is of importance to estimate to what extent human activities contribute to the recent warming trend observable at a regional and global scale. Terrestrial archives are of particular interest for such reconstructions since they can offer proxy time series of high temporal resolution developed within human habitat. Tree-ring based proxies have been frequently used for such reconstructions and the response of these proxies to climatic factors has been shown (e.g., Grudd et al., 2002; Hantemirov and Shiyativ, 2002; Naurzbaev et al., 2002). Long-time temperature sensitive tree-ring time series, however, are almost exclusively from high latitudes ( $>65^{\circ}$ north) and alpine timber lines where temperature is the most important growth limiting factor. Other terrestrial archives like lake sediments and speleothems also provide data for estimates of past temperature variability, but the quantification of proxy/climate relationships is complicated by missing direct linkages between climate parameter and proxies.

Peat bogs and fens form additional important terrestrial archives of past environmental and climate variability. They are widely distributed and cover a large part of the Earth's land surface often within human habitat (Charman, 2002). Due to partially high accumulation rates, they allow developing high resolution proxy records spanning several millennia (e.g., Mauquoy et al., 2008; Charman et al., 2009). Multiple botanical proxies (e.g., pollen and plant remains) are established and a range of methods have been developed to make inferences about Holocene environmental and climate dynamics (Warner and Charman 1994; Birks, 2003; Charman et al., 2009). Isotope-geochemical methods applied on peat deposits have also great potential to provide proxies for climate variability, because empirical relationships between the stable isotope composition of plant cellulose from typical bog species and different climatic parameters, including temperature and relative humidity, have been found (Proctor et al., 1992; Ménot and Burns, 2001; Zanazzi and Mora, 2005; Skrzypek et al., 2007). Thus, contrary to tree-ring time series, peat bogs and fens offer the possibility to perform climate reconstructions based on several biotic and abiotic proxies (Kühl et al., 2010).

Sphagnum is the most abundant peat forming genus in ombrotrophic bogs in northern and western Europe and is present in many late Holocene peat accumulations (Clymo, 1970). Sphagnum plant remains are, therefore, the ideal material to use in isotope-geochemical studies on peat deposits. Plant cellulose is usually used for stable isotope studies since isolation of a single chemical component reduces problems associated with changes in the relative proportion of chemical compounds over time (Rinne et al., 2005). Calibration studies have systematically investigated the relationship between climate parameters and the stable carbon isotope composition of cellulose $\left(\delta^{13} \mathrm{C}_{\text {cellulose }}\right)$ from modern Sphagnum plants. Ménot and Burns (2001) found that in addition to atmospheric $\mathrm{CO}_{2}$ partial pressure, temperature and water availability play significant roles for their $\delta^{13} \mathrm{C}_{\text {cellulose values. Re- }}$ garding potential relationships between the $\delta^{13} \mathrm{C}_{\text {cellulose of }}$ Sphagnum plant material and micro-climatological parameters, Skrzypek et al. (2007) report strong correlations between the $\delta^{13} \mathrm{C}_{\text {cellulose values of Sphagnum and air temper- }}$ ature during the growing season. The major problem in the application of the Sphagnum $\delta^{13} \mathrm{C}_{\text {cellulose }}$ to peat records in order to derive climatic signals arises from the finding that a significant offset exists between the stable carbon isotope composition of cellulose from different Sphagnum plant components (Loader et al., 2007; Moschen et al., 2009). Thus, physical separation of individual plant parts prior to isotope analyses is a necessity to avoid misinterpretations of stable isotope time series.

The aim of this study was to perform a high resolution climate reconstruction based on the stable carbon isotope composition of cellulose chemically extracted from selected well-identifiable Sphagnum plant components. This study is a test if the empirical relationship between the stable carbon isotope composition of Sphagnum and temperature found in calibration studies can be transferred to the palaeo-record. At Dürres Maar, a kettle-hole peat accumulated in a small maar crater, more than five metres of Sphagnum peat developed during the last 2000 yr. Dürres Maar, therefore, forms an outstanding archive to establish a high resolution stable carbon isotope time series spanning the last two millennia. The peat is situated in a region where human settlement and agriculture was highly variable during the last $2000 \mathrm{yr}$. We assess the resilience of this proxy to the potential human impact on the peat ecosystem by linking the isotope data with the results of palynological investigations and compare our reconstruction with suchlike based on other proxies, especially tree-ring chronologies.

\section{Background - the Sphagnum $\delta^{13} \mathrm{C}_{\text {cellulose } /}$ temperature dependency}

The photosynthetic uptake of $\mathrm{CO}_{2}$ by terrestrial plants leads to a fractionation of the carbon isotopes. During Sphagnum moss photosynthesis, which follows the $C_{3}$ photosynthetic pathway, a constant fractionation factor via the Rubisco carboxylation enzyme occurs, since the later preferentially uses ${ }^{12} \mathrm{CO}_{2}$ (Farquhar et al., 1982). In addition to this consistent fractionation, a number of environmental factors, including temperature, bog surface wetness, relatively humidity and $\mathrm{CO}_{2}$ partial pressure, affect the stable carbon isotope composition of Sphagnum plant material (Williams and Flanagan, 1996). Due to the closed coupling of several environmental factors to air temperature, a (presumably indirect) dependency of the stable carbon isotope composition of Sphagnum 
cellulose on local air temperature has been assumed. To date there is no laboratory study on this relationship, however, the Sphagnum $\delta^{13} \mathrm{C}_{\text {cellulose }} /$ temperature dependency has been proven in field studies (Ménot and Burns, 2001; Skrzypek et al., 2007). Alongside an altitudinal transect in the European Alps, in addition to the effect of decreasing atmospheric $\mathrm{CO}_{2}$ partial pressure with increasing altitude, both temperature and water availability, have been found to play significant roles for the $\delta^{13} \mathrm{C}_{\text {cellulose values of modern Sphag- }}$ num plants. As a result of this study, statistically significant $\Delta \delta^{13} \mathrm{C}_{\text {cellulose }} / \Delta T_{\text {air }}$ coefficients for Sphagnum magellanicum and Sphagnum capillifolium of $-0.41 \%{ }^{\circ} \mathrm{C}$ and $-0.20 \%{ }^{\circ} \mathrm{C}$ have been calculated. The different coefficients were attributed to differences in the leave anatomy of the two species potentially leading to variations in the $\mathrm{CO}_{2}$ diffusion resistance (Ménot and Burns, 2001). Sphagnum magellanicum (Sphagnum type) possesses oval photosynthetic cells which are fully enclosed by the water-filled hyaline cells. Sphagnum capillifolium (Acutifolia type) possesses triangleshaped photosynthetic cells which are exposed at the leave surface (Laine et al., 2009). It seems reasonable that the latter pattern leads to a lower diffusional resistance to $\mathrm{CO}_{2}$ uptake because of a potentially smaller aqueous barrier created by the hyaline cells.

Other field studies regarding the $\delta^{13} \mathrm{C}_{\text {cellulose }}$ /temperature relationship of modern Sphagnum plant material indicate that the stable carbon isotopic signatures recorded within different species are more related to the micro-topographic position of the Sphagnum plants within a bog or fen. Greater ranges of stable carbon isotope values in hollow species than in suchlike growing on relatively dry hummocks has been observed along surface moisture gradients on several European and sub-arctic Canadian bogs (Loisel et al., 2009). Higher variability in the stable carbon isotope values in hollow species can be an indication of variable carbon sources for Sphagnum photosynthesis in wet habitats, such as $\mathrm{CO}_{2}$ release by methanotrophic bacteria, likely complicating the relationship between the stable carbon isotope composition of Sphagnum cellulose and environmental variables (Markel et al., 2010). Additionally, ${ }^{13} \mathrm{C}$-depleted values of multiple Sphagnum species have been shown to be related to a low water table depth, while ${ }^{13} \mathrm{C}$-enriched values correspond to a water table close to the peat surface (Price et al., 1997). Thus, slightly different site specific hydrological conditions could, therefore, also explain the different temperature coefficients calculated for different Sphagnum species (Skrzypek et al., 2007). Whether the significantly different $\Delta \delta{ }^{13} C_{\text {cellulose }} / \Delta T_{\text {air }}$ coefficients for Sphagnum magellanicum and $S$. capillifolium depend on species-specific anatomical characteristics or on the micro-topographic position of individual Sphagnum moss pads within a bog or fen micro-habitat can be solely clarified by substantial plantphysiological investigations not performed on Sphagnum so far.
To summarize, there is evidence that the stable carbon isotope composition of Sphagnum cellulose reflects environmental conditions during plant growth and cellulose biosynthesis. There are a number of environmental factors that vary in concert with air temperature and, thus, it is difficult to separate the effects of temperature from other controls on the $\delta^{13} \mathrm{C}_{\text {cellulose of Sphagnum including relative humidity }}$ and the rainfall amount or the distribution and the resulting water table variation. Nevertheless, due to the closed coupling of most environmental factors to air temperature, the $\delta^{13} \mathrm{C}_{\text {cellulose }}$ of Sphagnum is a potential recorder of air temperature (Ménot and Burns, 2001; Skrzypek et al., 2007; Kaislahti Tillman et al., 2010).

\section{Study site}

Dürres Maar is a kettle-hole type peat deposit located in a small maar crater situated in the mountainous West Eifel Volcanic Field, Germany $\left(50^{\circ} 52^{\prime} \mathrm{N}, 6^{\circ} 53^{\prime} \mathrm{E}\right)$. The current mesotrophic bog has a diameter of 140-175 $\mathrm{m}$ with a surface area of $0.029 \mathrm{~km}^{2}$ and is $455 \mathrm{~m}$ a.s.l. The maximum elevation of the crater rim is $470 \mathrm{~m}$ a.s.l. (Fig. 1). The surface of the bog is wet, but walkable, and two vegetation zones can be distinguished, which are mainly due to hydrological conditions and nutrient supply. Closest to the edge and relatively wet is the lagg where Carex lasiocarpa and C. rostrata dominate and where fen species exist such as Potentilla palustris. A transitional zone follows towards the central relatively dry bog area where the vegetation consists of raised bog species. Dominating elements of the central bog are Sphagnum magellanicum and S. capillifolium var. rubellum in combination with Vaccinium oxycoccos and Eriophorum angustifolium. Several small birchs (Betula pubescens) and scattered small pines (Pinus sylvestris) cover the current bog (Fig. 2). The average growing season lasts from mid-April to mid-October (Forst et al., 1997).

\section{Material and methods}

\subsection{Core collection and sampling}

In 2007, we recovered a $5.5 \mathrm{~m}$ long core (core DM-01) in the relatively dry centre of Dürres Maar (Fig. 2). The core was taken using two different coring devices: the upper $3 \mathrm{~m}$ of peat were cored with a lopsided open peat corer (Eijkelkamp "Gouge auger") providing sections of $1 \mathrm{~m}$ in length and $6.0 \mathrm{~cm}$ in diameter. At greater depths, the peat contains some small sections of very watery peat requiring a different coring device in order to avoid core loss. The use of a Russian corer (Eijkelkamp "Peat sampler") at depths greater than $3 \mathrm{~m}$ avoided core loss due to the closure of the coring device. The Russian corer allowed us to core half-round sections of $50 \mathrm{~cm}$ length with a diameter of $5.5 \mathrm{~cm}$. After removing a section, 


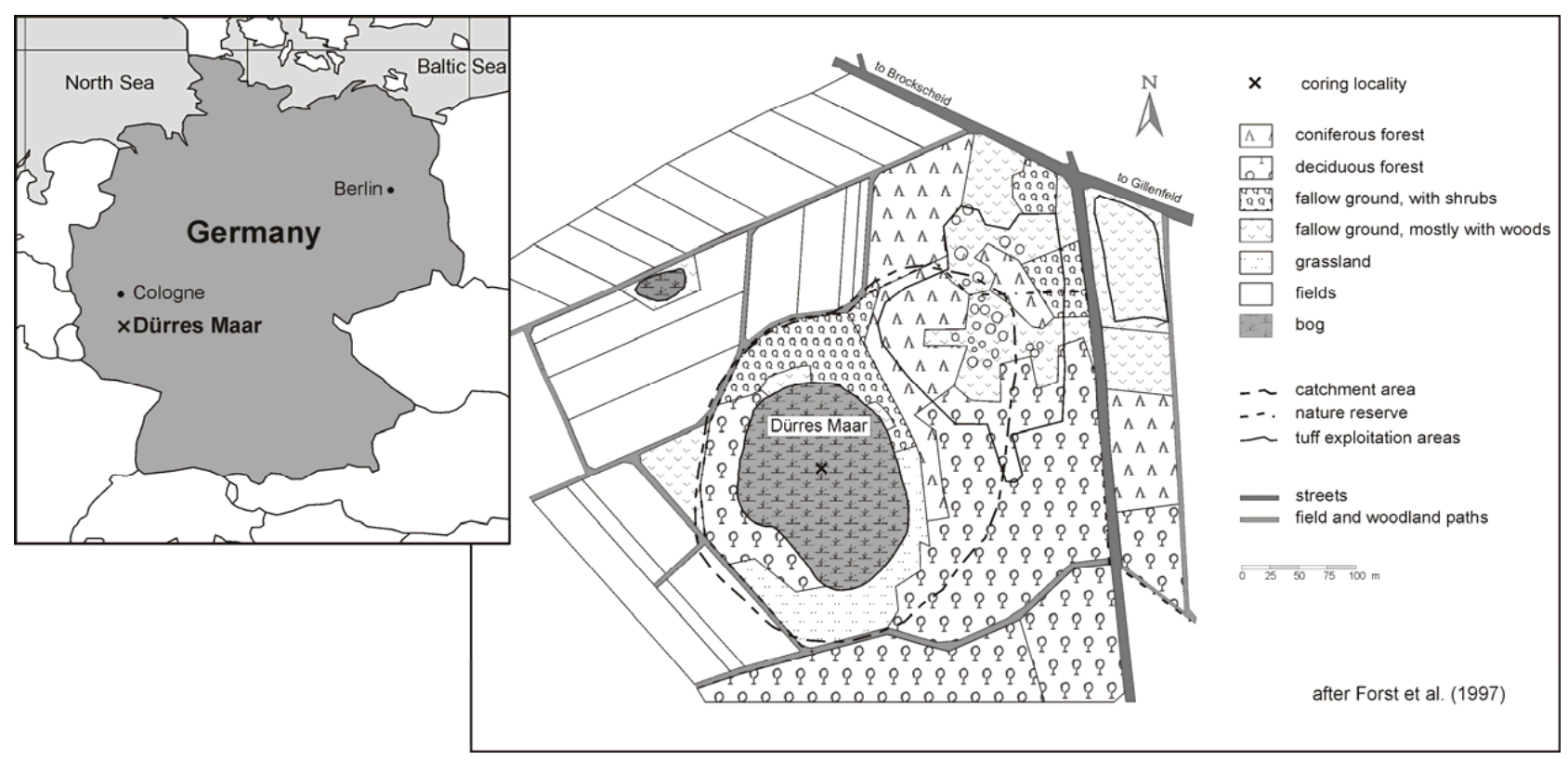

Fig. 1. Location of Dürres Maar and map of the hosted peat deposit and the surrounding vegetation cover (modified after Forst et al., 1997).

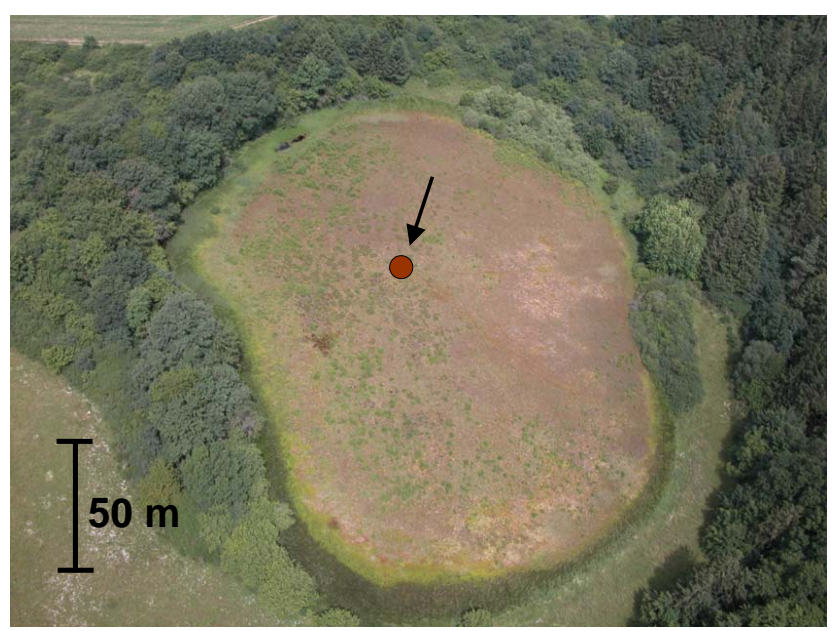

Fig. 2. Aerial photograph of Dürres Maar with borehole location.

the corer was cleaned with deionised water. Core sections were stored in a freezer at $-24^{\circ} \mathrm{C}$.

Each frozen core section was cut into $2 \mathrm{~cm}$ increments in the lab under room temperature using a stainless steel saw in combination with a mitre lay. The width of the blade is $1 \mathrm{~mm}$, which causes the loss of approximately $5 \%$ of each slice during cutting. Immediately after cutting, the outermost $\sim 2 \mathrm{~mm}$ of each deep frozen slice was removed and the samples were additionally washed carefully with deionised water to remove possible contamination with plant fragments originating from the lower depths or adheres to the core during field work (Givelet et al., 2004).

\subsection{Dating}

A total of twelve samples of core DM-01 were radiocarbon dated at the Poznañ Radiocarbon Laboratory, Poland (Table 1). Samples consist of pure Sphagnum plant fragments each representing a $2 \mathrm{~cm}$ depth interval. Pure Sphagnum is used for radiocarbon dating because Sphagnum plants grow in situ, do not have roots and grow in an upward direction from the plant's apex. Therefore, it is unlikely that they were transported from the vicinity to the central bog area where the core was taken. In one case (Sample Poz-23192 from a depth of 5.02-5.04 m), plant fragments from Vaccinium spec. were used for ${ }^{14} \mathrm{C}$ dating, because Sphagnum plant material was not available in adequate amounts. Details of the laboratory procedure are described by Czernik and Goslar (2001).

\subsection{Separation of Sphagnum plant material from bulk peat sediments}

To obtain reliable Sphagnum-specific stable isotope records from a peat deposit, which reflect environmental and climate dynamics, it is necessary to separate single Sphagnum plant components from the mixture of plant remains (Loader et al., 2007; Moschen et al., 2009). The manual separation of Sphagnum branches or stem sections for cellulose extraction and subsequent stable isotope measurement is, however, very time consuming and restricts the time resolution of potential stable isotope time series. Therefore, we have tested if sieving of the bulk peat samples into different size fractions can serve to substitute the separation of morphological parts of Sphagnum plants (Daley et al., 2009). To separate Sphagnum remains from the bulk peat samples, each sample was 
Table 1. Results of AMS radiocarbon dating: Sphagnum plant material is used for radiocarbon dating to avoid admixture of plant material relocated from the bog's vicinity. In one case $(*)$ plant fragments from Vaccinium spec. were used for ${ }^{14} \mathrm{C}$ dating, because Sphagnum plant material was not available in an adequate amount. The standard deviation for the calendar ages is given as $2 \sigma$. The sample from a depth between 502 and $504 \mathrm{~cm}$ was omitted from the model, since its ${ }^{14} \mathrm{C}$ age is obviously too young. These results depict the radiocarbon dating of the upper approximately $5.5 \mathrm{~m}$ of core DM- 01 with a total length of $\sim 7.5 \mathrm{~m}$. The age depth model of the entire core is shown in Moschen et al. (2009) and Kühl et al. (2010).

\begin{tabular}{lcrrr}
\hline depth $[\mathrm{cm}]$ & Lab. no. & ${ }^{14} \mathrm{C}$ age & age cal. BP & calendar age (2 $\sigma)$ \\
\hline $20-22$ & Poz-22240 & $130.27 \pm 0.39 \mathrm{pMC}$ & & $\mathbf{1 9 6 0 - 1 9 6 1}$ AD \\
$84-86$ & Poz-24702 & $640 \pm 30 \mathrm{BP}$ & $610-544$ & $\mathbf{1 3 6 8} \pm \mathbf{2 8}$ AD \\
$132-134$ & Poz-23191 & $890 \pm 30 \mathrm{BP}$ & $834-733$ & $\mathbf{1 1 6 7} \pm \mathbf{5 1}$ AD \\
$172-174$ & Poz-22243 & $1075 \pm 30 \mathrm{BP}$ & $1015-930$ & $\mathbf{9 7 8} \pm \mathbf{4 3}$ AD \\
$228-230$ & Poz-20797 & $1140 \pm 30 \mathrm{BP}$ & $1142-968$ & $\mathbf{8 9 5} \pm \mathbf{8 7}$ AD \\
$292-294$ & Poz-22244 & $1270 \pm 30 \mathrm{BP}$ & $1286-1167$ & $\mathbf{7 2 4} \pm \mathbf{6 0}$ AD \\
$356-358$ & Poz-20798 & $1490 \pm 30 \mathrm{BP}$ & $1416-1305$ & $\mathbf{5 9 0} \pm \mathbf{5 6}$ AD \\
$428-430$ & Poz-22246 & $1570 \pm 30 \mathrm{BP}$ & $1530-1393$ & $\mathbf{4 8 9} \pm$ 69 AD \\
$422-424$ & Poz-20799 & $1585 \pm 30 \mathrm{BP}$ & $1538-1405$ & $\mathbf{4 7 9} \pm \mathbf{6 7}$ AD \\
$472-474$ & Poz-20773 & $1650 \pm 30 \mathrm{BP}$ & $1622-1508$ & $\mathbf{3 8 5} \pm \mathbf{5 7}$ AD \\
$502-504$ & Poz-24706 & $1350 \pm 30 \mathrm{BP}$ & $1314-1235$ & $\mathbf{6 7 6} \pm \mathbf{4 0}$ AD \\
$520-522 *$ & Poz-23192 & $2125 \pm 35 \mathrm{BP}$ & $2160-1997$ & $\mathbf{1 2 9} \pm \mathbf{8 2}$ BC \\
$570-572$ & Poz-20800 & $2585 \pm 30 \mathrm{BP}$ & $2766-2701$ & $\mathbf{7 8 4} \pm \mathbf{3 3 ~ B C}$ \\
\hline
\end{tabular}

washed through a sieve stack with mesh sizes of 2000, 630, 355 and $200 \mu \mathrm{m}$. Before the sieving of bulk peat samples, approximately $5 \mathrm{~g}$ of wet peat was placed in $800 \mathrm{ml}$ beakers in deionised water on a heatable magnetic stirrer and was simmered for one hour at $85^{\circ} \mathrm{C}$. Subsequently, each sample was carefully sieved wet on the sieve stack with a minimum of 5 litres of deionised water. Due to simmering and sieving the peat samples were easily fragmented into single leaves, branch fragments and the less fragile stem sections. Each size fraction was examined for it's composition under a stereoscopic binocular microscope (Nikon SMZ 2B). The size fraction of $355-630 \mu \mathrm{m}$ has been identified to consist of almost pure Sphagnum leaves. Therefore, this size fraction was used for cellulose extraction and stable isotope measurement. Compared to the very time consuming manual separation of adequate amounts of single Sphagnum plant components for cellulose extraction, the use of this size fraction enables us to process an approximate five times higher amount of samples compared to hand-picking of plant components.

\subsection{Cellulose extraction and stable carbon isotope measurements}

We have chemically extracted cellulose from a total of 257 samples using an improved extraction method based on sample bleaching with sodium chlorite and a following cellulose dissolution and re-precipitation with cuprammonium solution (CUAM). After conventional sodium chlorite bleaching following the method described by Ménot and Burns (2001), cellulose was dissolved in the CUAM solution $\left(\left[\mathrm{Cu}\left(\mathrm{NH}_{3}\right)_{4}\right](\mathrm{OH})_{2}\right)$ and re-precipitated using sulphuric acid (Wissel et al., 2008). Contrary to the Ménot and Burns method, no solvent extraction stage prior to the extraction of cellulose was carried out, since this step has been found to be not essential for the purification of cellulose, even from resinous woods (Rinne et al., 2005). Compared to conventional methods, the CUAM approach achieves pristine cellulose not by removing any contaminants from the cellulose, but by dissolving the cellulose from bulk peat samples. That way, contaminations of Sphagnum cellulose with small amounts of minerogenic matter like silt and clay and/or biogenic opal as well as of residual non-cellulose organic compounds could be excluded. Additionally, the received cellulose is very homogenous ensuring isotopic homogeneity when using small sample amounts for isotope measurements. After freeze-drying the extracted cellulose, a cellulose yield (given in percentages by weight) was determined representing the amount of cellulose dissolved and re-precipitated from a freeze-dried sample of Sphagnum leaves.

Stable carbon isotope ratios of Sphagnum cellulose were measured by on-line combustion of 200-300 $\mu \mathrm{g}$ dry cellulose weighed into tin foil cups and combusted at $1080^{\circ} \mathrm{C}$ using an EuroEA elemental analyser (Euro Vector Instruments, Italy) to generate $\mathrm{CO}_{2}$ for an interfaced IsoPrime continuous flow isotope ratio mass spectrometer ( $\mathrm{GV}$ Instruments, United Kingdom). Results are reported using the conventional $\delta$-notation $\left(\delta=\left(R_{\mathrm{S}} / R_{\mathrm{St}}-1\right) * 1000\right)$ with $R_{\mathrm{S}}$ and $R_{\mathrm{St}}$ as isotope ratios $\left({ }^{13} \mathrm{C} /{ }^{12} \mathrm{C}\right)$ of samples and stan-

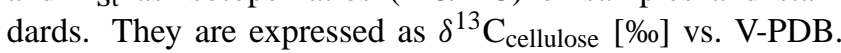
USGS24 graphite and IAEA-C3 cellulose were used as certified reference materials. Two internal standards (Fluka cellulose and graphite 4) were used for drift corrections. The 


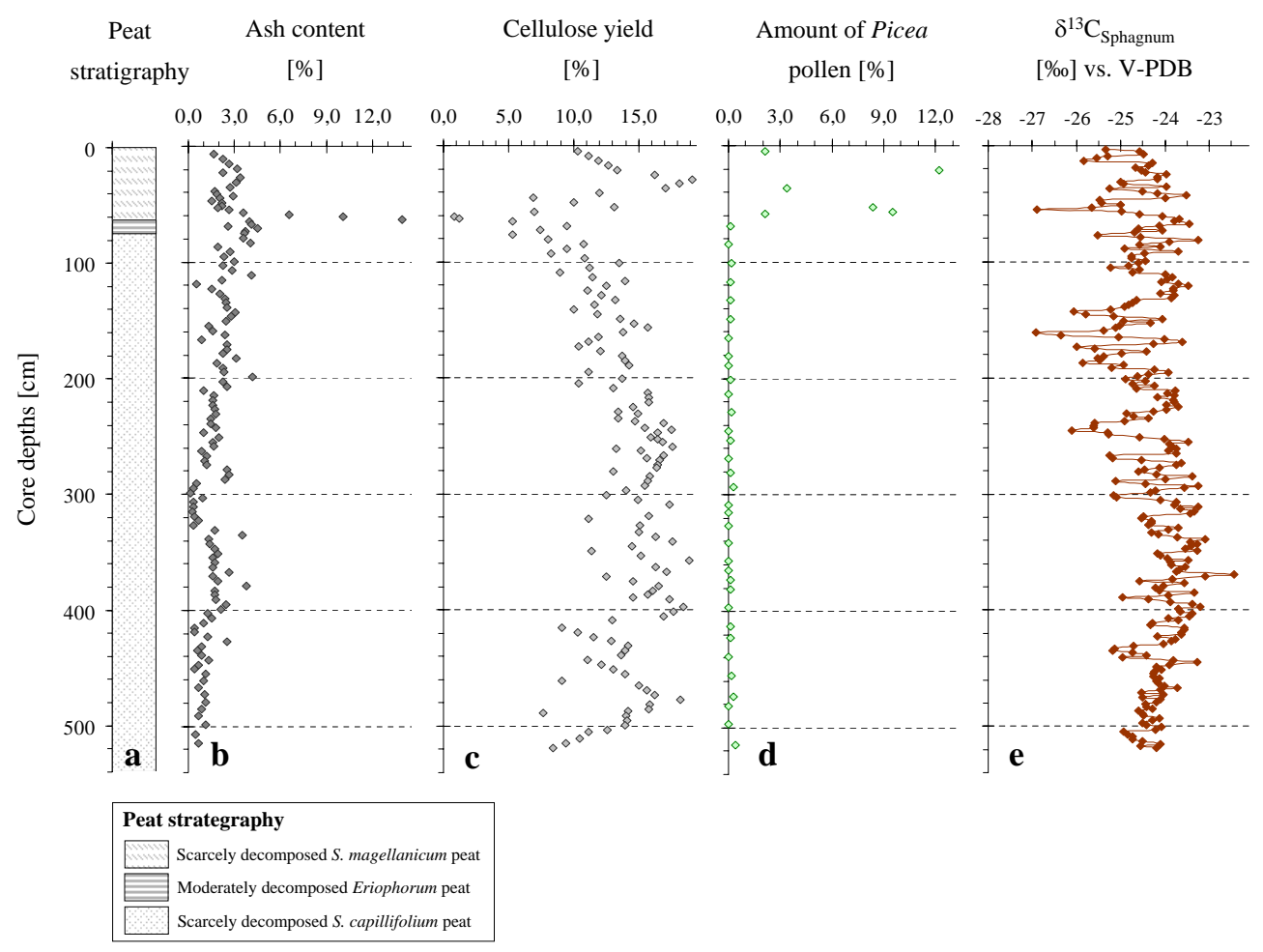

Fig. 3. The stable carbon isotope composition of Sphagnum cellulose (e) in combination with the peat stratigraphy of the upper $\sim 5.2 \mathrm{~m}$ of core DM-01 (a), the ash content of the bulk peat material (b), the cellulose content of Sphagnum leaves (c), and the Picea pollen concentration (d) of selected samples from core DM-01. No error bars are added to the individual symbols of figure (e) because the overall precision of replicate analyses is better than $\pm 0.1 \%$ and the error bars, thus, would be smaller than the symbol size.

analytical precision measured by replicate cellulose standards was $\pm 0.06 \% \circ(1 \sigma)$. Every tenth sample was measured twice to check the reliability of the measurements. The overall precision of these replicate analyses was better than $\pm 0.1 \%$ o $(1 \sigma)$.

Anthropogenic fossil fuel burning which increases the concentration of atmospheric $\mathrm{CO}_{2}$ have resulted in a lowering of the $\delta^{13} \mathrm{C}$ value of air by about $1.7 \%$ since industrialisation. Therefore, all $\delta^{13} \mathrm{C}$ values of samples younger than $\mathrm{AD} 1850$ were corrected for this effect by adding a $\delta^{13} \mathrm{C}$ correction factor according to Table 2 to the measured data (Leuenberger, 2007).

\subsection{Ash content}

Determination of the ash content has been carried out on the bulk peat material from core DM-01 and follows a four step method described in detail by Kempter (1996). After an initial evaporation of moisture at room temperature, about $0.5 \mathrm{~g}$ of bulk peat was subsequently oven dried at $105^{\circ} \mathrm{C}$ and cooled down to room temperature in a desiccator. After the determination of the dry weight using a micro balance with an accuracy-range of $0.001 \mathrm{mg}$ (Mettler Toledo XP25) samples were immediately igniting oven combusted in a muffle furnace at $600{ }^{\circ} \mathrm{C}$ for $6 \mathrm{~h}$. Hereafter, the weight of the resid- ual was determined after cooling the samples to room temperature in a desiccator using the same micro balance and expressed in percentage of the dry weight.

\section{Results and discussion}

\subsection{Sphagnum peat stratigraphy, age-depth model and peat accumulation}

Most of the sediments of Dürres Maar consist of scarcely decomposed highly organic Sphagnum peat (Fig. 3a). From its basis at $\sim 5.20 \mathrm{~m}$ to a depth of $\sim 0.70 \mathrm{~m}$ the profile predominantly consists of Sphagnum capillifolium var. rubellum plant fragments (Moschen et al., 2009) and the minerogenic proportion of the peat is on average around $2 \%$. At a depth of $\sim 70 \mathrm{~cm}$ a pronounced alteration in the peat structure and composition is obvious and both, the plant macro-fossil and geochemical composition considerably change. A section with higher decomposition appears consisting of a mixture of Eriophorum and Sphagnum plant fragments. The uppermost four centimetres of this section $(60-64 \mathrm{~cm})$ are dominated by Eriophorum leaf sheaths and Sphagnum is only present in a very small amount. This section shows, by far, the highest ash content of the entire profile (Fig. 3b). 
Table 2. Measured $\delta^{13} \mathrm{C}$ values of Sphagnum cellulose chemically extracted from the samples which are younger than $1850 \mathrm{AD}$, corresponding $\delta^{13} \mathrm{C}$ correction factors calculated from annual correction factors shown in Leuenberger (2007), and the resulting Sphagnum $\delta^{13} \mathrm{C}_{\mathrm{cellul}}$ values corrected for the Suess effect, i.e., the antropogenically induced increase in atmospheric ${ }^{13} \mathrm{CO}_{2}$ (values in bold). On the basis of our age-depth model a top age and a bottom age for each sample was calculated narrowing the time span any $2 \mathrm{~cm}$ peat increment accumulated to a specific number of years (full years). Each $\delta^{13} \mathrm{C}$ correction factor was calculated as a mean of six to seven annual correction factors (Leuenberger, 2007) corresponding to the time span each individual peat increment has been accumulated.

\begin{tabular}{|c|c|c|c|c|c|c|}
\hline $\begin{array}{l}\text { sample } \\
\text { number }\end{array}$ & $\begin{array}{l}\text { top } \\
\text { age }\end{array}$ & $\begin{array}{r}\text { bottom } \\
\text { age }\end{array}$ & $\begin{array}{r}\text { mean } \\
\text { age }\end{array}$ & $\begin{array}{r}\text { measured } \\
\delta^{13} \mathrm{C}_{\text {cellulose }} \\
{[\% \text { ] vs. V-PDB }}\end{array}$ & $\begin{array}{r}\delta^{13} \mathrm{C} \\
\text { cor. factor } \\
{[\% o] \text { vs. V-PDB } *}\end{array}$ & $\begin{array}{r}\text { corrected } \\
\delta^{13} \mathbf{C}_{\text {cellulose }} \\
{[\% \text { o vs. V-PDB }}\end{array}$ \\
\hline 1 & 2003 & 1998 & 2001 & $-26,76$ & 1,735 & $-25,02$ \\
\hline 2 & 1998 & 1994 & 1996 & $-26,04$ & 1,600 & $-24,44$ \\
\hline 3 & 1994 & 1990 & 1992 & $-25,85$ & 1,486 & $-24,36$ \\
\hline 4 & 1990 & 1985 & 1987 & $-26,53$ & 1,355 & $-25,17$ \\
\hline 5 & 1985 & 1981 & 1983 & $-26,65$ & 1,220 & $-25,43$ \\
\hline 6 & 1981 & 1976 & 1979 & $-26,85$ & 1,090 & $-25,76$ \\
\hline 7 & 1976 & 1972 & 1974 & $-25,20$ & 0,960 & $-24,24$ \\
\hline 8 & 1972 & 1968 & 1970 & $-25,18$ & 0,840 & $-24,34$ \\
\hline 9 & 1968 & 1963 & 1965 & $-25,41$ & 0,708 & $-24,71$ \\
\hline 10 & 1963 & 1959 & 1961 & $-25,20$ & 0,600 & $-24,60$ \\
\hline 11 & 1959 & 1954 & 1957 & $-25,03$ & 0,563 & $-24,47$ \\
\hline 12 & 1954 & 1950 & 1952 & $-24,48$ & 0,538 & $-23,95$ \\
\hline 13 & 1950 & 1946 & 1948 & $-24,63$ & 0,514 & $-24,12$ \\
\hline 14 & 1946 & 1941 & 1943 & $-24,58$ & 0,487 & $-24,09$ \\
\hline 15 & 1941 & 1937 & 1939 & $-25,36$ & 0,462 & $-24,90$ \\
\hline 16 & 1937 & 1932 & 1935 & $-25,26$ & 0,435 & $-24,83$ \\
\hline 17 & 1932 & 1928 & 1930 & $-24,26$ & 0,408 & $-23,85$ \\
\hline 18 & 1928 & 1924 & 1926 & $-25,52$ & 0,384 & $-25,14$ \\
\hline 19 & 1924 & 1919 & 1921 & $-24,76$ & 0,358 & $-24,40$ \\
\hline 20 & 1919 & 1915 & 1917 & $-24,40$ & 0,332 & $-24,07$ \\
\hline 21 & 1915 & 1910 & 1913 & $-23,72$ & 0,305 & $-23,42$ \\
\hline 22 & 1910 & 1906 & 1908 & $-24,20$ & 0,280 & $-23,92$ \\
\hline 23 & 1906 & 1902 & 1904 & $-25,65$ & 0,256 & $-25,40$ \\
\hline 24 & 1902 & 1897 & 1899 & $-25,61$ & 0,230 & $-25,38$ \\
\hline 25 & 1897 & 1893 & 1895 & $-25,16$ & 0,204 & $-24,96$ \\
\hline 26 & 1893 & 1888 & 1891 & $-25,81$ & 0,177 & $-25,63$ \\
\hline 27 & 1888 & 1884 & 1886 & $-27,03$ & 0,168 & $-26,86$ \\
\hline 28 & 1884 & 1880 & 1882 & $-25,11$ & 0,170 & $-24,94$ \\
\hline 29 & 1880 & 1875 & 1877 & $-24,69$ & 0,162 & $-24,53$ \\
\hline 30 & 1875 & 1870 & 1873 & $-24,15$ & 0,156 & $-23,99$ \\
\hline 31 & 1871 & 1866 & 1869 & $-23,78$ & 0,148 & $-23,63$ \\
\hline
\end{tabular}

${ }^{*}$ Given $\delta^{13} \mathrm{C}$ correction factors are an approximation, however, since the differences between the individual annual factors are smaller than $0.05 \%$, this approximation is a sufficient correction for the Suess effect (for details see Leuenberger et al., 2007).

Simultaneously the amount of Sphagnum cellulose yielded by the CUAM extraction was very low, pointing to intensified degradation of the Sphagnum plant material (Fig. 3c). Above, again scarcely decomposed Sphagnum peat developed and in turn a very small minerogenic proportion (on average between 2 and $3 \%$ ) can be observed. The moss composition of this section, however, differs from the underlying approximately $4.5 \mathrm{~m}$ of almost pure Sphagnum capillifolium var. rubellum peat. In the upper $\sim 60 \mathrm{~cm}$ of the profile, the dominating moss species is Sphagnum magellanicum which is accompanied by small amounts of S. palustre and S. capillifolium var. rubellum (Moschen et al., 2009). Remains from Cyperaceae, Vaccinium, or Erica are very rare.
The occurrence of the Eriophorum dominated peat section and the high ash content above several metres of scarcely decomposed, highly organic Sphagnum peat indicate a major rearrangement of the mire ecosystem. We hypothesize that the Eriophorum peat section follows considerable peat cutting. Such peat cutting during the 19th century has been already assumed by Kempter (1996) and Forst et al. (1997), but was never examined in detail. The Dürres Maar peat deposit is situated in a small maar crater without any surficial outflow. Peat cutting, thus, would result in a shallow wet marsh, first re-colonised by Eriophorum spec. and much more adapted to a wet habitat and inundation than Sphagnum mosses (Wieder and Vitt, 2006). Afterwards 


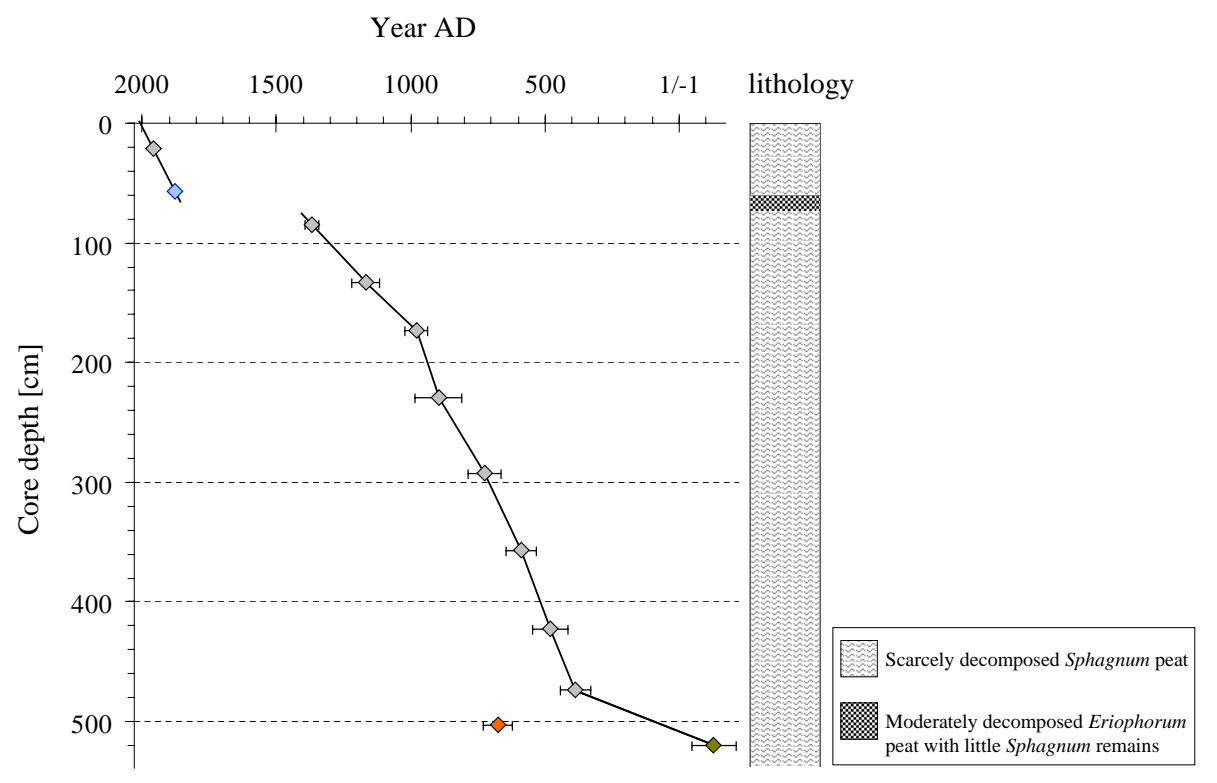

Fig. 4. Age-depth model and lithology of core DM-01 taken in the centre of the Dürres Maar peat deposit. The model is based on 10 ${ }^{14} \mathrm{C}$ results calibrated and transformed to calendar ages (years AD) using CALIB 5.0 (Reimer et al., 2004). The age at a depth of between 56 and $58 \mathrm{~cm}$ (blue diamond) is determined on the basis of the palynological investigation performed on selected samples of the profile (for details see Sect. 5.1). The sample from a depth between 502 and $504 \mathrm{~cm}$ was omitted from the model, since its ${ }^{14} \mathrm{C}$ age is obviously too young. In one case (dark green diamond) plant fragments from Vaccinium spec. were used for ${ }^{14} \mathrm{C}$ dating, because Sphagnum plant material was not available in an adequate amount.

a rearrangement of the bog's ecosystem would take place and in turn a Sphagnum-dominated ecosystem developed, whereby peat formation progress until today. This succession would also explain the high ash content of the Eriophorum dominated peat section and the low Sphagnum cellulose yield, indicating a reduction in the peat accumulation rate and a simultaneously higher aerobic decomposition of the plant material. Summarised, above several metres of scarcely decomposed, highly organic Sphagnum peat, a considerable disturbance is obvious which is interpreted as a result of peat cutting. In consequence, the profile consists of a deeper Sphagnum capillifolium var. rubellum dominated section and an upper S. magellanicum dominated section.

The age-depth model for core DM-01 provides additional information for a division of the profile into two sections. Ten ${ }^{14} \mathrm{C}$ values (Table 1) and a palynological examination of selected samples of the profile (for details see Kühl et al., 2010) form the basis for establishing the model. From the bottom at $\sim 5.20 \mathrm{~m}$ to a depth of $\sim 0.70 \mathrm{~m}$ the model indicates two phases of considerably different peat accumulation rates (Fig. 4). After $\sim 400 \mathrm{yr}$ with a relatively low peat accumulation rate of $\sim 1 \mathrm{~mm} \mathrm{yr}^{-1}$, an increase to $\sim 5 \mathrm{~mm} \mathrm{yr}^{-1}$ is obvious. This increase corresponds well with a significant shift to lower pollen concentrations in the bulk peat samples supporting higher peat accumulation (Kühl et al., 2010). After another $\sim 600 \mathrm{yr}$ a slight decrease to about $3 \mathrm{~mm} \mathrm{yr}^{-1}$ at $\sim$ AD $980(\sim 1.7 \mathrm{~m})$ could be identified. At least until the middle 15th century, the age-depth model is consistent and confirmed by various radiocarbon data. During a time span of more than $1500 \mathrm{yr}$ about $4.5 \mathrm{~m}$ of scarcely decomposed and highly organic peat has been accumulated.

The model for the upper section of the profile is comparatively poor. Because only one radiocarbon data is available, we have established the model for this upper section by the aid of the palynological investigation. The available AMS value of the sample from a depth of $20-22 \mathrm{~cm}$ is 130 pMC and reflects the bomb peak of atmospheric ${ }^{14} \mathrm{C}$ in the middle of the 20th century. The amount of 130pMC occurred twice, between AD 1960 and AD 1961 and in AD 1979 (Goslar et al., 2005). Thus, two different peat accumulation rates are possible. If the sample from a depth of 20 $22 \mathrm{~cm}$ matches AD 1960-1961 the mean peat accumulation rate is $\sim 4.5 \mathrm{~mm} \mathrm{yr}^{-1}$, if this sample matches AD 1979 the mean accumulation rate is $\sim 8 \mathrm{~mm} \mathrm{yr}^{-1}$. Although a constant accumulation rate from the bog's surface to a depth of $\sim 65 \mathrm{~cm}$ is not very likely, both accumulation rates seem reasonable. The palynological examination provides evidence that a mean accumulation rate of $\sim 4.5 \mathrm{~mm} \mathrm{yr}^{-1}$ is the best approximation. At a depth of 56-58 cm, core DM-01 displays the first appearance of a larger quantity of Picea pollen ( $9.5 \%$ of the total pollen sum) indicating the existence of Picea forests in the vicinity of Dürres Maar (Fig. 3d). The high Picea pollen sum is clearly attributable to the afforestation of the Eifel low mountain range with Picea abies under Prussian governance (Schwind, 1984). In the West Eifel Volcanic Field large-scale Picea abies afforestation started 
around AD 1850 (Wacker, 1991). According to the start of the Prussian afforestation and since Picea abies trees need a minimum of $30 \mathrm{yr}$ before they produce larger amounts of pollen (Schmidt-Vogt et al., 1986), we estimate the mean age of the sample from a depth of $56-58 \mathrm{~cm}$ to a maximum of $\sim A D$ 1880. This value supports the assumption that the mean peat accumulation rate of the upper section of the profile is $\sim 4.5 \mathrm{~mm} \mathrm{yr}^{-1}$. Although this approximation disregards any peat compaction which certainly takes place, in particular, at the transition from the fresh uncompacted acrotelm to the underlying catotelm peat, this is the best assumption on the basis of the three anchor points of the agedepth model of the younger section of our profile (Fig. 4). To summarize, a hiatus divides the profile into two independent sections and a former portion of peat lying inbetween nearly $\sim 1 \mathrm{~m}$ thickness accumulated during approximately $400 \mathrm{yr}$ must have been cut. Whether such a large amount of peat was removed during one substantial intervention or smaller amounts of peat being cut several times after another cannot be answered.

\subsection{Estimating the past growing season temperature variability at Dürres Maar}

Today Sphagnum magellanicum is the dominating moss species in the central relatively dry area of Dürres Maar and the scarcely decomposed peat accumulated during the last approximate $150 \mathrm{yr}$ almost exclusively consists of $S$. magellanicum plant remains. In contrast, the underlying peat sequence developed from $\mathrm{AD} 1$ to $\sim \mathrm{AD} 1450$ almost exclusively consists of $S$. capillifolium var. rubellum plant remains (Moschen et al., 2009). Both taxa are typical raised bog species and common in late Holocene peat deposits in western Europe (Frahm and Frey, 2004; Mauquoi and van Geel, 2007). For both species, a dependency of their $\delta^{13} \mathrm{C}_{\text {cellulose values on growing season temperature has }}$ been shown and statistically significant $\Delta \delta^{13} \mathrm{C} / \Delta T$ coefficients were determined (Ménot and Burns, 2001). We have used the data concerning the $\delta^{13} \mathrm{C}_{\text {cellulose values of }}$ S. capillifolium and S. magellanicum shown in Fig. 2 and the corresponding temperature data of Table 1 of Ménot and Burns (2001) to estimate transfer functions regarding the temperature $/ \delta^{13} \mathrm{C}_{\text {cellulose }}$ relationship for both species $(T=$ $-2.35 * \delta^{13} \mathrm{C}_{\text {cellulose }}-46.35$ for $S$. capillifolium $\left(R^{2}=0.51\right)$ and $T=-0.82 * \delta{ }^{13} \mathrm{C}_{\text {cellulose }}-8.969$ for $S$. magellanicum $\left.\left(R^{2}=0.28\right)\right)$. The first transfer function was applied on the $S$. capillifolium var. rubellum dominated peat section developed from $\mathrm{AD} 1$ to $\sim \mathrm{AD} 1450$, the second on the $S$. magellanicum dominated section grown after the rearrangement of the bog ecosystem in the first half of the 19th century (Fig. 5a). Additionally, the corresponding $95 \%$ prediction intervals were calculated for both time intervals (Fig. 5b). Although statistically significant, the $\Delta \delta^{13} \mathrm{C} / \Delta T$ coefficients for $S$. capillifolium and $S$. magellanicum published by Ménot and Burns (2001) were obtained on a large dispersion of points. Therefore, the use of this data basis to establish transfer functions regarding the temperature $/ \delta^{13} \mathrm{C}_{\text {cellulose }}$ relationship of Sphagnum to estimate past growing season temperatures results in overall relatively high uncertainties. Nevertheless, Fig. 5b illustrates the reconstructed local growing season temperature (GST) at Dürres Maar showing considerable centennial and decadal scale variability. After four centuries of moderate GST variations and slightly above average GST values, at $\sim \mathrm{AD} 400$, a transition to lower temperatures is indicated. It coincides with a remarkable increase in the peat accumulation rate pointing to more favourable growth conditions for Sphagnum and, thus, to a relatively high water table. Onset and duration of the reconstructed cold and presumably also relatively wet phase, is in accordance with the so called European Migration Period from the 4th to the 7th century AD, that marked the transition from the Late Roman Period to the Early Middle Ages and is described as time span with poor living conditions in central Europe (Fouracre, 2005). For this time span, a marked decline in land use is documented for the West Eifel region (Litt et al., 2009).

In the following, a transition to higher temperatures is obvious which goes along with an increase in the highfrequency signal magnitude whereby multiple distinct colder and warmer episodes at maximum lasting a few decades are detectable. During High Medieval Times lasting from the 10th to 13th century, our reconstruction shows evidence for above-average temperatures, whereby the amplitude in the reconstructed temperature variability is most likely overestimated. However, temperatures were not high in general; rather distinct warmer episodes lasting a few decades are demonstrated. Afterwards the reconstructed GST gradually decreases to average and slightly below-average temperatures during the 14th and 15th century. In contrast to the temperature anomalies during the European Migration Period and at High Medieval Times, the temperature signal of the Little Ice Age (LIA) is not preserved in our archive due to considerable peat cutting that most likely took place in the first half of the 19th century. Nevertheless, peat cutting during the 19th century, when the Eifel region was considerably deforested (Schwind, 1984), refers to poor living conditions presumably accompanied by low temperatures because peat was used as solid fuel and stable litter (Forst et al., 1997).

Despite the overall relatively high uncertainty in our reconstruction and the certainly overestimated temperature variability particularly at High Medieval Times, the centennial scale variations of our reconstructed palaeo-GST at Dürres Maar are in accordance with climate reconstructions on the basis of lake sediments and historical datasets from western and north-western Europe (e.g., Hammarlund et al., 2003; Brázdil et al., 2005). Results from the Swiss Alps indicate several glacial retreats during a period lasting from the 9th to 12th century (Holzhauser et al., 2005). In the Italian Alps, temperatures presumably have reached higher values than nowadays during the 11th and 12th century when soils developed on mountain slopes presently characterised 

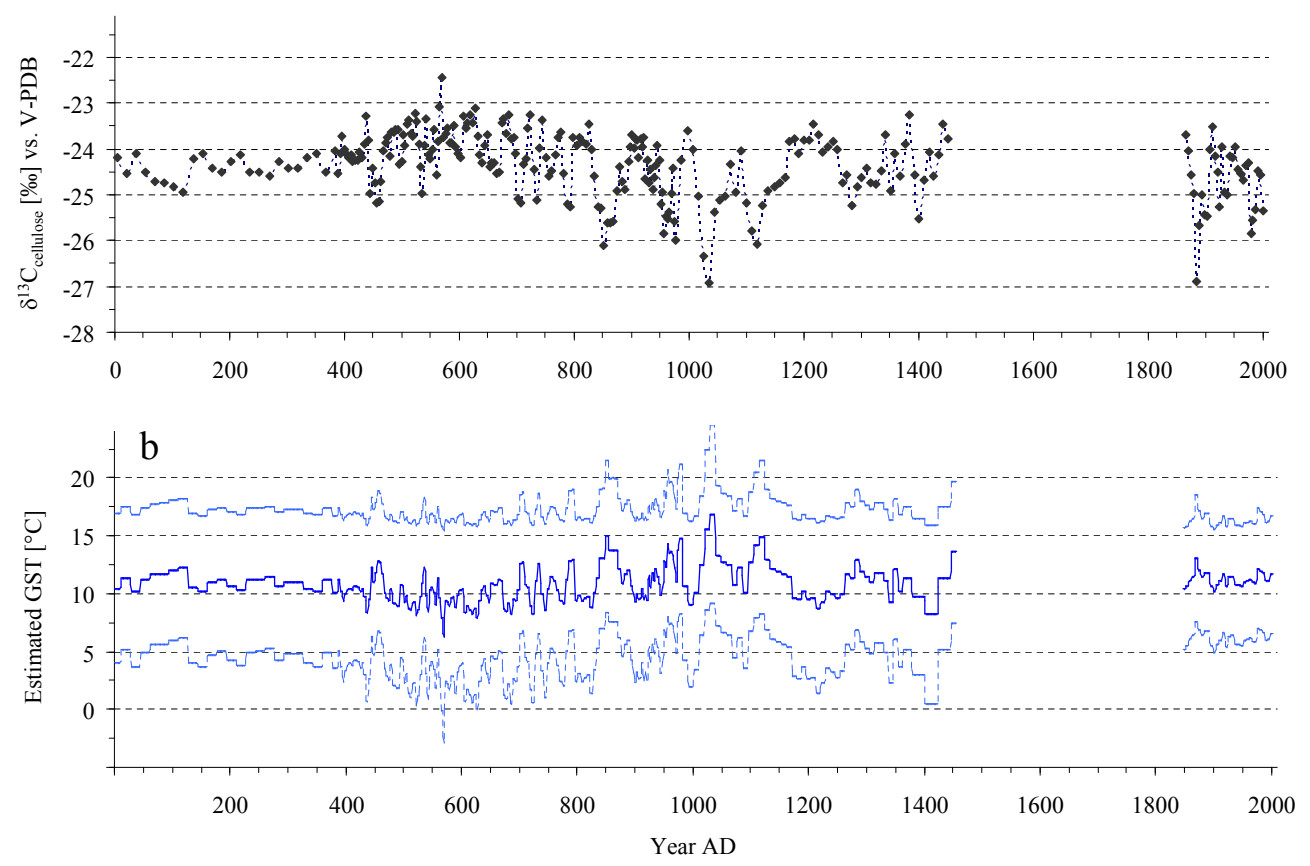

Fig. 5. The stable carbon isotope composition of Sphagnum cellulose (a) in combination with the estimated growing season temperature at Dürres Maar (b). On the basis of our age-depth model, a top age and a bottom age for each sample was calculated narrowing the time span and $2 \mathrm{~cm}$ peat increment accumulated to a specific number of years. Calculating a top and bottom age for each individual sample, thus, enabling the generating of estimated temperature values for each year of the time period under investigation. They are given in Fig. $5 \mathrm{~b}$ which also contains the lower and upper limit of the prediction interval. Due to the dispersed small quantity of values (10 for $S$. magellanicum and 7 for $S$. capillifolium) the predicted error is relatively large.

by periglacial debris (Giraudi, 2009). At Medieval Times, two phases of distinct ice retreat are also described for Norwegian glaciers. The most pronounced retreat during the last two millennia has been dated to AD 1000 (Nesje et al., 2001). Although one has to take into account that the time resolution of the reconstructions on the basis of glacier advances and retreats is relatively poor compared to the Sphagnum $\delta^{13} \mathrm{C}_{\text {cellulose }}$ time series presented here, these proxies also show distinct periods during High Medieval Times where temperatures were probably as high as today or even higher.

Unlike the above-average temperatures at High Medieval Times and slightly before, we do not find evidence for any prior warm phase. Although our reconstruction shows slightly above-average temperatures during the second half of the 1st century AD, a Late Roman Climate Optimum often described as similar warm or even warmer as medieval times could not be detected. This is in accordance with other millennial-scale climate reconstructions based on multiple proxy datasets (e.g., Jones and Mann, 2004; Moberg et al. 2005). In contrast to these reconstructions in favour of the absence of a pronounced Roman Climate Optimum, there are other proxy records that point to relatively high temperatures during the first two centuries AD. Proxies of glacier retreat and low lake levels indicate warm and/or dry conditions in the Alps (Holzhauser et al., 2005; Joerin, et al., 2006; Gi- raudi, 2009). On the contrary, a record of reconstructed temperatures derived from a well-dated stalagmite $\delta^{18} \mathrm{O}_{\mathrm{CaCO} 3}$ record from the Central Alps shows remarkably low winter temperatures during the first four centuries AD (Mangini et al., 2005). The results of Mangini et al. (2005) suggest that the climate of this period was continental and dry. Thus, the dryness of the climate rather than its warmth would explain the widely accepted glacier recession accompanied by low lake levels in the Alps during the Late Roman Period.

Due to their annual resolution, tree-ring data series offer the highest accuracy possible regarding the age control of terrestrial proxy time series (e.g., Briffa et al., 2004). Figure 6 shows the estimated GST temperature at Dürres Maar compared to the recently developed central European summer temperature reconstruction of Büntgen et al. (2011) which is based on multiple standardized tree-ring width series. Although the age-depth control of our reconstructed GST is doubtless not as precise as that of the signals derivable from the tree-ring series, from $\mathrm{AD} 1$ to $\sim \mathrm{AD} 850$, the agreement of both reconstructions is remarkable. Also during the 19th and 20th century both reconstructions resemble each other. Thus, during these time spans, the multicentennial low frequency European climate signal is preserved in our record. Simultaneously, the two series disagree on decadal time scale. Given that our estimated GST is a local signal, whereas the Büntgen et al. (2011) record is a large-scale average of tree-ring data 


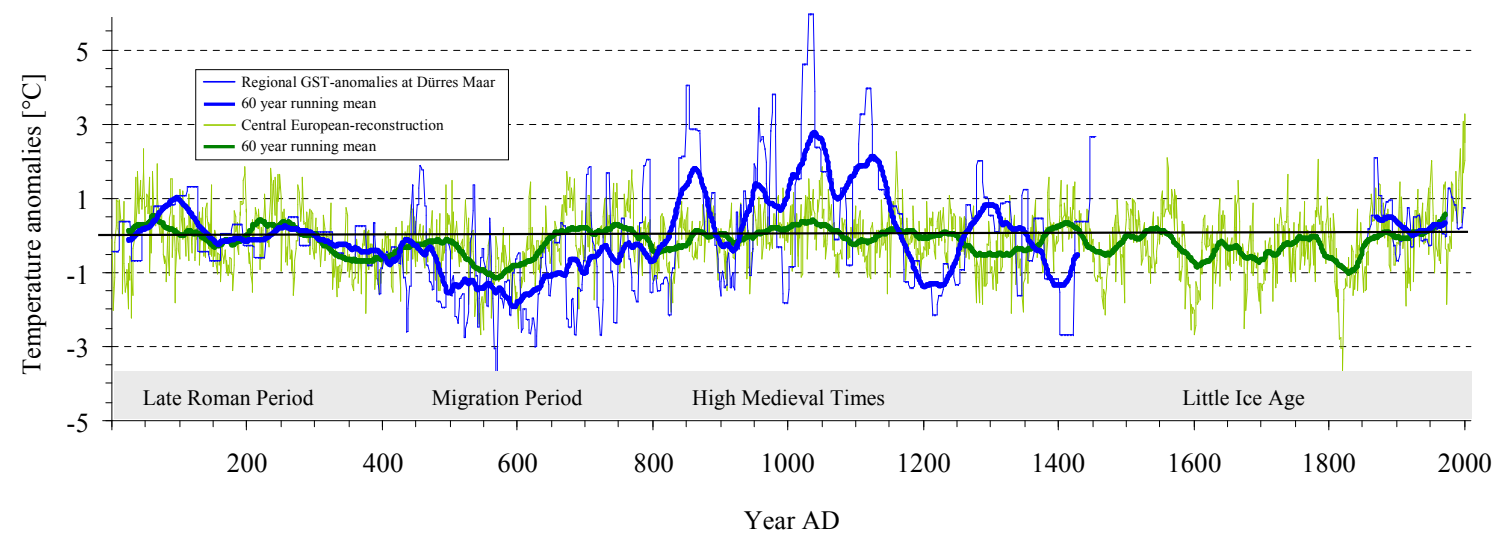

Fig. 6. The estimated growing season temperature (GST) anomalies at Dürres Maar compared to the western European temperature reconstruction of Büntgen et al. (2011) which is based on multiple standardized tree-ring width series. Both proxy datasets are not scaled to any observational record. The bolt lines show the $60 \mathrm{yr}$ running means.

from western Europe, it is not surprising that both records do not fit on decadal time scale, since temperature reconstructions on a local scale are known to exhibit notable differences compared to central European reconstructions (Bradley et al., 2003; Wanner et al., 2005). It is, however, also probable that the offset in timing is caused by the less precise age-depth control of our record compared to the annually resolved treering series. Nevertheless, it is important to note that both reconstructions show the same multicentennial climate variability. This is superimposed by high frequency variability with multiple narrow intervals of the highest warmth or relatively low temperatures. Thus, contrary to the impression that most multi-proxy and multi-site climate reconstructions might give, our results confirm regional inconsistency in natural climate variability (Hughes and Diaz, 1994; Crowley and Lowery, 2000). Such is known from modern meteorological observations indicating that decadal scale climate variability is no global nor northern hemispheric phenomenon, rather temperature trends vary by region and season. For example, while current warming and accompanied reduced sea ice cover is prevalent over most of the Arctic, some areas, such as Greenland, appear to be cooling.

From the 9th to the 13th century, the two reconstructions show remarkable differences in the magnitude of reconstructed temperature variability. Although prominent phases of Medieval warmth are described in several northern hemispheric temperature reconstructions, the amplitude of reconstructed temperatures of up to c. $1^{\circ} \mathrm{C}$ is much smaller than our GST amplitude during High Medieval Times which is at c. $6^{\circ} \mathrm{C}$ (e.g., Crowley and Lowery, 2000; Esper et al., 2003; Moberg et al., 2005). It is increasingly unclear why our reconstruction of GST matches the Büntgen et al. (2011) central European summer temperature reconstruction for several centuries during the first Millennium AD, however, overestimating the GST during phases of most prominent medieval warmth. As described above, with regard to the $\delta^{13} \mathrm{C}_{\text {cellulose }}$ of Sphagnum used as proxy for temperature variability, an overestimation of the growing season temperature is particularly the case when GST is relatively high and the amount of spring and summer rainfall simultaneously decreases. Under these conditions the water supply to the photosynthetic cells of Sphagnum is reduced, resulting in ${ }^{13} \mathrm{C}$-depleted stable carbon isotope values of Sphagnum cellulose and, thus, to an overestimation of the reconstructed GST.

One additional circumstance that has possibly led to an overestimation of the true variability is that we have to presuppose a linear response between the $\delta^{13} \mathrm{C}_{\text {cellulose of Sphag- }}$ num and temperature. If this response is nonlinear in nature, which is often likely in the case of biological systems, our interpretation necessarily becomes erroneous. This is particularly likely if the reconstructed temperature variability falls outside the range of temperatures in the calibration dataset (in our case $\sim 9-16^{\circ} \mathrm{C}$ ). If the magnitude of warming during High Medieval Times in the West Eifel Volcanic Field was more pronounced during the warmer season of the year, and the relationship between seasons was not stationary in time, our reconstruction overestimates the medieval warming.

\subsection{Testing the reliability of the estimated GST anomaly - the calibration dataset}

In contrast to the results from the older section of the peat sequence, the chronological control of our Sphagnum $\delta^{13} \mathrm{C}_{\text {cellulose }}$ time series from the upper section has to be considered with caution (see Sect. 5.1). Nevertheless, relatively long time series of instrumental data are available and allows us examine the relationship between the Sphagnum $\delta^{13} \mathrm{C}_{\text {cellulose }}$ values and measured growing season temperatures (GST). The nearest long lasting daily temperature dataset in the surrounding of Dürres Maar is from the meteorological station Trier $\sim 35 \mathrm{~km}$ to the southwest which is operated by the German Meteorological Survey (DWD). The observations started at AD 1907, but lack the time period 


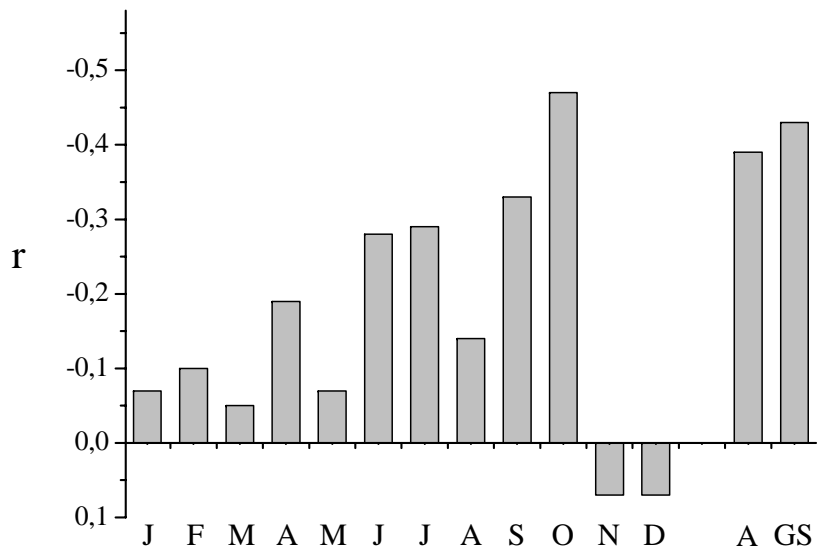

Fig. 7. Linear correlations between the Sphagnum $\delta^{13} \mathrm{C}_{\text {cellulose }}$ values and average temperatures based on daily temperature data (1907-2004) from the meteorological station Trier $\sim 35 \mathrm{~km}$ to the Southwest of Dürres Maar $(n=21)$. Bars 1-12 represent the correlations between the $\delta^{13} \mathrm{C}$ values and mean monthly temperatures (January-December); A represents the correlation between the Sphagnum $\delta^{13} \mathrm{C}_{\text {cellulose values and the mean annual tempera- }}$ ture; GS represents the correlation $\delta^{13} \mathrm{C}$ values and the mean growing season temperature (15.04.-15.10.). Average monthly-, growing season-, and growing season temperature were calculated for each $\sim 4.5 \mathrm{yr}$ time interval to maintain the same temporal resolution than the peat samples (for details see Sect. 5.3).

from 1935 to 1947. Assuming a more or less linear peat accumulation rate during the time span of meteorological observations, i.e., the last $\sim 100 \mathrm{yr}$, each single $2 \mathrm{~cm}$ peat increment has been theoretically accumulated during $\sim 4.5 \mathrm{yr}$. Therefore, the individual Sphagnum $\delta^{13} \mathrm{C}_{\text {cellulose values were }}$ compared to average growing season temperatures calculated for each $\sim 4.5 \mathrm{yr}$ time interval to maintain the same temporal resolution than the peat samples. Due to the Sphagnum $\delta^{13} \mathrm{C}_{\text {cellulose/temperature relationship shown in calibra- }}$ tion studies (Ménot and Burns, 2001; Skrzypek et al., 2007) and since a significant correlation between the $\delta^{13} \mathrm{C}_{\text {cellulose }}$ values of Sphagnum and summer temperature has recently been reported for Sphagnum fuscum from subarctic Canada (Kaislahti Tillman et al., 2010), a good agreement between our Sphagnum $\delta^{13} \mathrm{C}_{\text {cellulose values and the respective mean }}$ GST was expected. However, a relatively low correlation $(r=0.43)$ was found which is only slightly higher than the dependency of the Sphagnum $\delta^{13} \mathrm{C}_{\text {cellulose values on the re- }}$ spective mean annual temperatures $(r=0.39)$ (Fig. 7).

The correlation between our estimated GST and the corresponding instrumental temperature data is certainly hampered by two main reasons: First, the chronological control of the Sphagnum $\delta^{13} \mathrm{C}_{\text {cellulose }}$ calibration dataset is not very reliable (see Sect. 5.1). Due to solely three anchor points within $\sim 65 \mathrm{~cm}$ of scarcely decomposed peat, a linear peat accumulation rate has to be assumed. Such a linear accumulation over a period of about $100 \mathrm{yr}$ is not very likely and would additionally imply that no compaction of the peat took

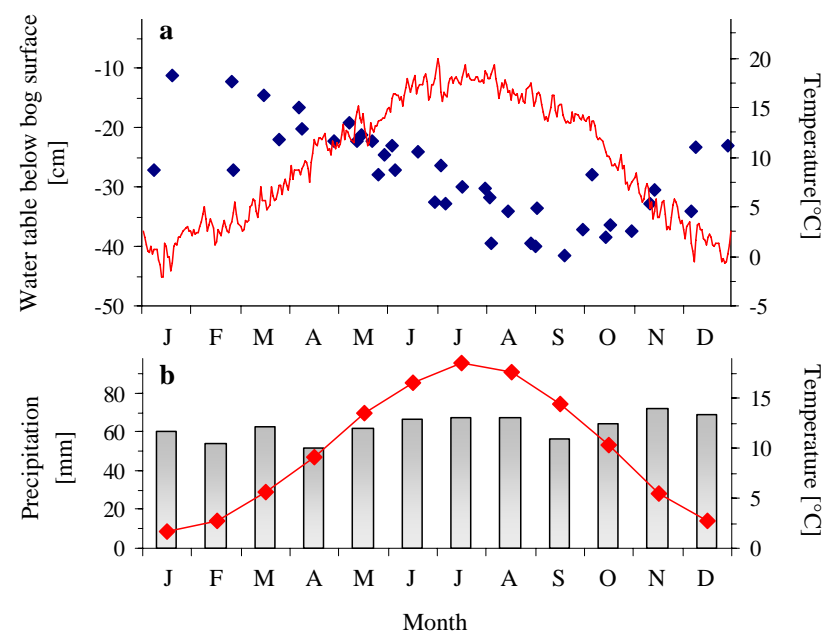

Fig. 8. Water table fluctuations in the centre of Dürres Maar (dark blue diamonds) in combination with average daily temperatures (a) and monthly sum of precipitation in combination with average monthly temperatures (1961-1990) (b). Water table fluctuations were measured from April 1991 until December 1993 by Forst et al. (1996). The depicted average daily temperatures for the years 1991, 1992 and 1993 were recorded at the meteorological station Manderscheid approximately $6 \mathrm{~km}$ to the south of Dürres Maar operated by the German Meteorological Service. Also the monthly sum of precipitation and the average monthly temperatures of the time period from 1961 until 1990 were recorded at Manderscheid.

place over time. Second, one has to consider that a variety of environmental variables are integrated by the Sphagnum

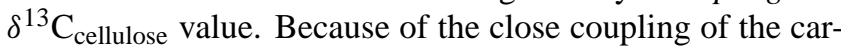
bon isotope signal to the diffusional limitation of $\mathrm{CO}_{2}$ supply, which is controlled by the thickness of the water film surrounding the plant's chloroplasts, precipitation amount and distribution, relative humidity and, thus, the bog surface wetness most likely plays a major role. On the other hand, in the central relatively dry bog area of Dürres Maar, water table fluctuations are significantly related to local temperature, whereas there is a lack of response to the amount or distribution of precipitation (Fig. 8). This is in accordance with the finding of Schoning et al. (2005) who demonstrated that water table fluctuations in two ombrotrophic mires in central Sweden are closely related to changing temperature conditions while there is no correlation to fluctuations in precipitation amount and distribution. Consequently, despite overall relatively low correlation coefficients for the temperature/Sphagnum $\delta^{13} \mathrm{C}$ relationship, we assume that at Dürres Maar local temperature is linked with the factors directly forcing the carbon isotope fractionation by Sphagnum mosses, i.e., the diffusional resistance to $\mathrm{CO}_{2}$ uptake through the aqueous barrier surrounding the plants chloroplasts and the rate of photosynthesis. 


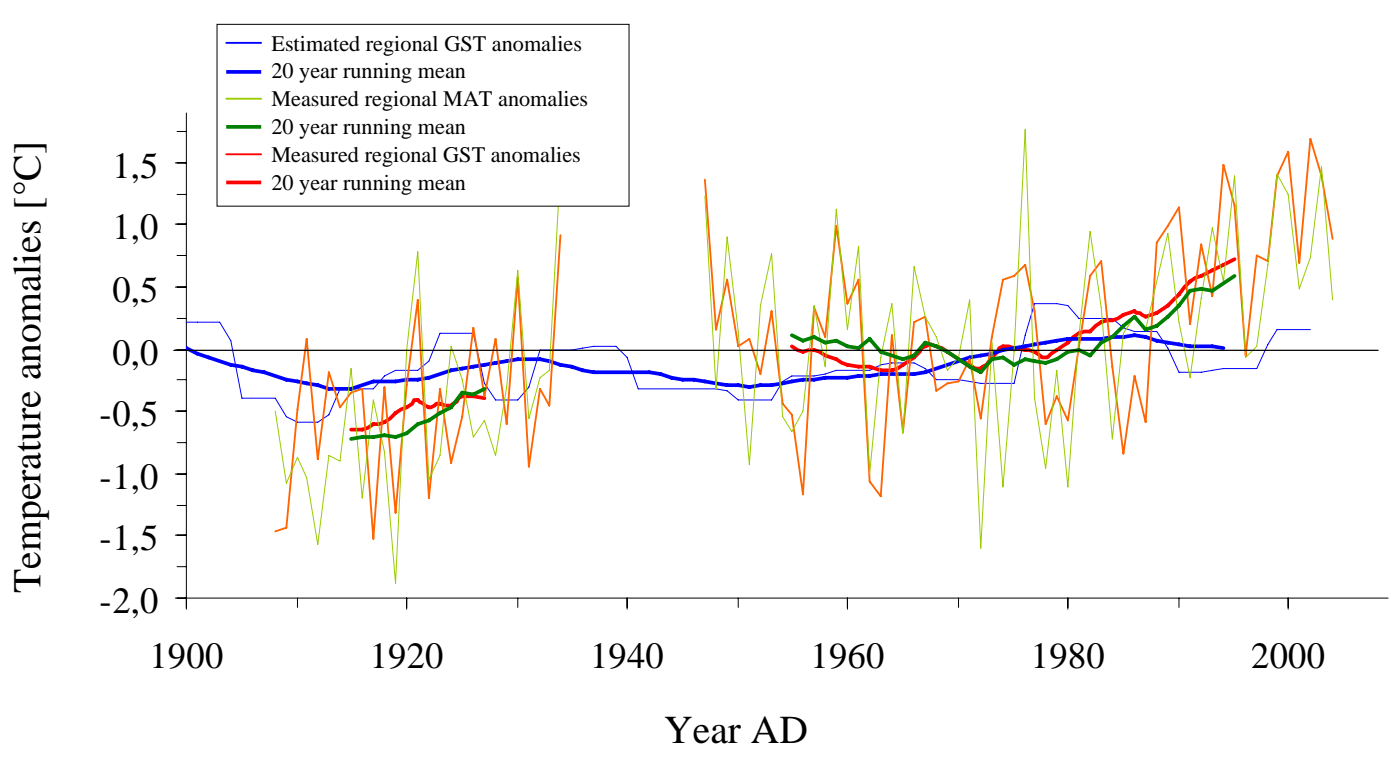

Fig. 9. Estimated growing season temperature anomalies (GST) at Dürres Maar in combination with calculated mean annual air temperature (MAT) anomalies and calculated growing season temperature anomalies (GST). Averaged temperatures are based on daily temperature data (1907-2004) from the meteorological station Trier $\sim 35 \mathrm{~km}$ to the Southwest of Dürres Maar. For comparison of proxy and instrumental data, the individual time series were scaled using 1961-1990 as the calibration period. The bolt lines show the 20 yr running means.

Our reconstructed GST, however, underestimate the measured GST which is on average $\sim 2.0^{\circ} \mathrm{C}$ higher than our reconstructed values (Fig. 9). The reason can be seen in the coupling of the stable carbon isotope signal to the diffusional limitation of $\mathrm{CO}_{2}$ supply described above. Rising temperature lowers the water table below the bog surface and the water supply to the photosynthetic cells of the Sphagnum plants decreases. This leads to a reduced diffusional limitation of $\mathrm{CO}_{2}$ supply and relatively low Sphagnum $\delta^{13} \mathrm{C}_{\text {cellulose val- }}$ ues from which relatively low temperatures will be reconstructed. Our reconstructed GST also underestimate the interannual temperature variability. Compared to the amplitude of $\geq 3.0^{\circ} \mathrm{C}$ in the instrumental annually mean temperature and the respective growing season temperature values, our reconstructed GST amplitude of $\sim 1.6^{\circ} \mathrm{C}$ is rather small (Fig. 9). Even though an application of the temperature coefficient resulting from our calibration dataset of $-0.44 \% /{ }^{\circ} \mathrm{C}$, which is slightly higher than the published coefficient of $-0.41 \%{ }^{\circ} \mathrm{C}$ for S. magellanicum (Ménot and Burns, 2001), wouldn't enlarge the amplitude of reconstructed GST significantly. On the other hand side, each single sample of Sphagnum plant material used for the calibration dataset has been accumulated during the approximate $4.5 \mathrm{yr}$. Consequently each Sphagnum $\delta^{13} \mathrm{C}_{\text {cellulose value integrates the temperature }}$ information of up to five vegetation periods. If one compares the reconstructed GST anomalies with a five year running mean of instrumental vegetation period temperatures, the reconstructed amplitude of $\sim 1.1^{\circ} \mathrm{C}$ stands opposite to amplitude of $\sim 1.6^{\circ} \mathrm{C}$ as derived from the instrumental annually mean temperatures. Thus, the amplitude of our recon- structed GST anomalies is comparable to instrumental data. Nevertheless, part of the underestimation of the temperature variability by our reconstruction must originate from another reason. This phenomenon has been previously described for tree-ring based reconstructions of temperature variability and was attributed to the overwhelming problem that a proxy is not controlled by one single environmental variable (e.g., Büntgen et al., 2005; Corona et al., 2010). Sphagnum plants and trees, however, certainly react in very different ways on climate variables. For Sphagnum both, relative growth rate and biomass productivity are linked to temperature and the plants water content (Rice, 2000; Robroek et al., 2007). The maximum rate of $\mathrm{CO}_{2}$ assimilation and, thus, the highest biomass productivity has been found at a water content of approximately 7 (weight of fresh vs. dry Sphagnum plants). Above and below this value $\mathrm{CO}_{2}$ assimilation declined (Williams and Flanagan, 1996). In contrast, the discrimination against ${ }^{13} \mathrm{CO}_{2}$ is a more or less linear function of water content. The higher the water content is the

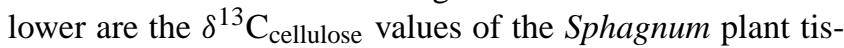
sue (Williams and Flanagan, 1996). We, hereof, hypothesize that the underestimation of the instrumental temperature data by our reconstruction partially results from the overall high biomass productivity at mean water content. At higher and lower water content (associated with lower and higher temperatures; Fig. 8), cellulose synthesis is reduced and the proportion of cellulose with depleted or enriched $\delta^{13} \mathrm{C}$ values is relatively small leading to a dampening of the amplitude of the stable carbon isotope time series of Sphagnum cellulose. 


\section{Conclusions}

A high resolution reconstruction of local growing season temperature (GST) spanning the last two millennia was established on the basis of the stable carbon isotope composition of Sphagnum cellulose from a kettle-hole peat deposit. The reconstructed GST shows relevant centennial and decadal scale variability. From the 4th to the 7 th century AD a cold, and presumably also wet, phase with below-average temperature is reconstructed which is in accordance with the so-called European Migration Period marking the transition from the Roman Period to the Early Middle Ages. Despite an overall overestimation of the most prominent warm phases, during High Medieval Times above-average temperatures are obvious. Most notably, temperatures were not low or high in general, rather high frequency temperature variability with multiple narrow intervals of below- and aboveaverage temperatures lasting a few decades is demonstrated. In contrast, a pronounced Late Roman Climate Optimum often described as similar warm or even warmer as medieval times could not be detected. The reconstructed GST shows a remarkable agreement with the Central European temperature reconstruction based on tree-ring datasets and is also in accordance with climate reconstructions on the basis of lake sediments and glacier advances and retreats. The good agreement between our reconstructed GST and the Büntgen et al. (2011) temperature reconstruction on centennial time scale indicates the advantage of performing temperature reconstructions on the basis of Sphagnum $\delta^{13} \mathrm{C}_{\text {cellulose }}$ datasets. Due to often high peat accumulation rates in raised bogs

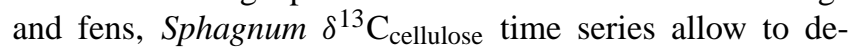
velop high resolution proxy records spanning several millennia. In contrast, most of the environmental and temperature reconstructions which have been processed from local tree-ring chronologies, span the last $\sim 300$ to $\sim 600$ yr only. From such proxy records much evidence of a Little Ice Age cooling is reported for different regions around the North Atlantic. Few tree-ring datasets that extended back prior to $\sim$ AD 1000 also assess the climatic variability during Medieval Times (e.g., Hantemirov et al., 2002; Naurzbaev et al., 2002; Büntgen et al., 2006). Because of the scarcity of wood material from the first millennium AD, the European Migration Period and the Late Roman Period are not well documented (Nicolussi et al., 2009). This applies, in particular, to western Europe. Although the time resolution of Sphagnum $\delta^{13} \mathrm{C}_{\text {cellulose }}$ datasets would not reach an annual resolution tree-ring datasets provide, an extension of climate reconstructions until the middle Holocene or even longer is possible.

Acknowledgements. We thank Georg Heumann, Thomas Litt, Jörn Parplies and Nils Riedel for assistance in the field. The help of Stefanie Wagner during core sampling is greatly acknowledged. Stable isotope measurements were carried out by Holger Wissel at the Institute of Bio- and Geosciences, Agrosphere. This work was supported by a grant of the Deutsche Forschungsgemeinschaft (German Research Foundation) to Robert Moschen (grant MO 1401/2-2).

Edited by: M. Fuchs

\section{References}

Birks, H. J. B.: Quantitative palaeoenvironmental reconstructions from Holocene biological data, in: Global Change in the Holocene, edited by: Mackay, A., Battarbee, R., Birks, H. J. B., Oldfield, F., Arnold, London, 107-123, 2003.

Bradley, R. S., Hughes, M. K., and Diaz, H. F.: Climate in medieval time, Science, 302, 404-405, 2003

Brázdil, R., Pfister, C., Wanner, H., von Storch, H., and Lutterbacher, J.: Historical climatology in Europe - the state of the art, Climatic Change, 70, 363-430, 2005.

Briffa, K. R.: Annual climate variability in the Holocene: interpreting the message of ancient trees, Quaternary Sci. Rev., 19, 87-105, 2000.

Briffa, K. R., Osborn, T. J., and Schweingruber, F. H.: Large-scale temperature inferences from tree rings: a review, Global Planet. Change, 40, 11-26, 2004.

Büntgen, U., Esper, J., Frank, D. C., Nicolussi, K., and Schmidhalter, M.: A 1052-year tree-ring proxy for Alpine summer temperatures, Clim. Dynam., 25, 141-153, 2005.

Büntgen, U., Tegel, W., Nicolussi, K., McCormik, M., Frank, D., Trouet, V., Kaplan, J. O., Herzig, F., Heussner, K.-U., Wanner, H., Luterbacher, J., and Esper, J: 2500 years of European climate variability and human susceptibility, Science, 331, 578582, 2011.

Charman, D. J.: Peatland and Environmental Change, John Wiley and Sons, Chichester, 2002.

Charman, D. J., Barber, K. E., Blaauw, M., Langdon, P. G., Mauquoy, D., Daley, T. J., Hughes, P. M. D., and Karofeld, E.: Climate drives for peatland palaeoclimate records, Quaternary Sci. Rev., 28, 1811-1819, 2009.

Clymo, R. S.: The growth of Sphagnum: Methods of Measurement, J. Ecol., 58, 13-49, 1970.

Corona, C., Guiot, J., Edouard, J. L., Chalié, F., Büntgen, U., Nola, P., and Urbinati, C.: Millennium-long summer temperature variations in the European Alps as reconstructed from tree rings, Clim. Past, 6, 379-400, doi:10.5194/cp-6-379-2010, 2010.

Crowley, T. J. and Lowery, T. S.: How warm was the Medieval Warm Period?, Ambio, 29, 51-54, 2000.

Czernik, J. and Goslar, T.: Preparation of graphite targets in the Gliwice Radiocarbon Laboratory for AMS ${ }^{14} \mathrm{C}$ dating, Radiocarbon, 43, 283-291, 2001.

Daley, T. J., Barber, K. E., Street-Perrott, F. A., Loader, N. J., Marshall, J. D., Crowley, S. F., and Fisher, E. H.: Holocene climate variability revealed by oxygen isotope analysis of Sphagnum cellulose from Walton Moss, northern England, Quaternary Sci. Rev., 29, 1590-1601, 2009.

Esper, J., Krusic, P. J., Peters, K., and Schweingruber, F. H.: Tests of the RCS method for preserving low-frequancy variability in long tree-ring chronlogies, Tree-Ring Res., 59, 81-98, 2003.

Esper, J., Wilson, R. S. J., Frank,, D. C, Moberg, A., Wanner, H., and Lutterbacher, J.: Climate: past ranges and future changes, Quaternary Sci. Rev., 24, 2164-2166, 2005. 
Farquhar, G. D., O'Leary, M. H., and Berry, J. A.: On the relationship between carbon isotope discrimination and the inter-cellular carbon dioxide concentration in leaves, Aust. J. Plant Physiol., 9, 121-137, 1982

Forst, M., Hierlmeier, R., Kiebel, A., and Ruthsatz, B.: Hoch- und Zwischenmoore in Trockenmaaren der Vulkaneifel, Angewandte Landschaftsökologie 14, Bundesamt für Naturschutz, Bonn-Bad Godesberg, Germany, 1997 (in German).

Fouracre, P. (Ed.): The New Cambridge Medieval History, Cambridge University Press, 1, c.500-c.700, doi:10.2277/0521362911, 2005.

Frahm, J.-P. and Frey, W.: Moosflora, Ulmer, Stuttgart, Germany, 2004 (in German).

Giraudi, C.: Late Holocene glacial and periglacial evolution in the upper Orco Valley, northwestern Italian Alps, Quaternary Res., 71, 1-8, 2009.

Givelet, N., Le Roux, G., Cheburkin, A., Chen, B., Frank, J., Goodsite, M. E., Kempter, H., Krachler, M., Noernberg, T., Rausch, N., Rheinberger, S., Roos-Barraclough, F., Sapkota, A., Scholz, C., and Shotyk, W.: Suggested protocol for collecting, handling and preparing peat cores and peat samples for physical, chemical, minerlogical amd isotopic analyses, J. Environ. Monitor., 6, 481-492, 2004.

Goslar, T., van der Knaap, O. W., Hicks, S., Andriè, M., Czernik, J., Goslar, E., Räsänen, S., and Hyötylä, H.: Radiocarbon dating of modern peat profiles: Pre- and post-bomb ${ }^{14} \mathrm{C}$ variations in the construction of age-depth models, Radiocarbon, 27, 115134, 2005.

Grudd, H., Briffa, K. R., Karlén, W., Bartholin, T. S., Jones, P. D., and Kromer, B.: A 7400-year tree-ring chronology in northern Swedish Lapland: natural climatic variability expressed on annual to millennial timescales,. The Holocene, 12, 657-665, 2002.

Hammarlund, D., Björck, S., Buchardt, B., Israelson, C., and Thomsen, C. T.: Rapid hydrological changes during the Holocene revealed by stable isotope records of lacustrine carbonates from Lake Igelsjön, southern Sweden, Quaternary Sci. Rev., 22, 353370,2003

Hantemirov, R. M. and Shiyatov, S. G.: A continuous multimillennial ring-width chronology in Yamal, northwestern Siberia, The Holocene, 12, 717-726, 2002.

Holzhauser, H., Magny, M., and Zumbuhl, H. J.: Glacier and lakelevel variations in west-central Europe over the last 3500 years, The Holocene, 15, 789-801, 2005.

Hughes, M. K. and Diaz, H. F.: Was there a "Medieval Warm Period", and if so, where and when?, Climatic Change, 26, 109142, 1994

Joerin, U. E., Stocker, T. F., and Schlüchter, C.: Multicentury glacier fluctuations in the Swiss Alps during the Holocene, The Holocene, 16, 697-704, 2006.

Jones, P. D. and Mann, M. E.: Climate over past Millennia, Review of Geophysics, 42 pp., doi:10.1029/2003RG000143, 2004.

Kaislahti Tillman, P., Holzkämper, S., Kuhry, P., Sannel, A. B. K., Loader, N. J., and Robertson, I.: Stable carbon and oxygen isotopes in Sphagnum fuscum peat from subarctic Canada: Implications for palaeoclimate studies, Chem. Geol., 270, 216-226, 2010.

Kempter, H.: Der Verlauf des anthropogenen Elementeintrages in Regenwassermoore Mitteleuropas während des jüngeren Holozäns. Paläoklimaforschung 26. Gustav Fischer Verlag.,
Stuttgart, Jena. p. 309, 1996 (in German).

Kühl, N., Moschen, R., Wagner, S., Brewer, S., and Peyron, O.: A multiproxy record of late Holocene natural and anthropogenic environmental change from the Sphagnum peat bog Dürres Maar, Germany: implications for quantitative climate reconstructions based on pollen, J. Quaternary Sci., 25, 675-688, 2010.

Laine, J., Harju, P., Timonen, T., Laine, A., Tuittila, E.-S., Minkkinen, K., and Vasander, H.: The intrinsic beauty of Sphagnum mosses - a Finnish guide to identification, Univerity of Helsinki Department of Forest Ecology Publications, 39, 1-190, 2009.

Leuenberger, M.: To what extend can ice core data contribute to the understanding of plant ecological developments of the past, Terrestrial Ecology, 1, 211-233, 2007.

Litt, T., Schölzel, C., Kühl, N., and Brauer, A.: Vegetation and climate history in the Westeifel Volcanic Field (Germany) during the last 11,000 years based on annually laminated lacustrine maar sediments, Boreas, 38, 679-690, 2009.

Loader, N. L., McCarroll, D., van der Knaap, W. O., Robertson, I., and Gagen, M.: Characterising carbon isotopic variability in Sphagnum, The Holocene, 17, 403-410, 2007.

Loisel, J., Garneau, M., and Hélie, J. F.: Modern Sphagnum $\delta^{13} \mathrm{C}$ signatures follow a surface moisture gradient in two boreal peat bogs, James Bay lowlands, Québec, J. Quaternary Sci., 24, 209_ 214, 2009.

Mangini, A., Spötl, C., and Verdes, P.: Reconstruction of temperature in the Central Alps during the past 2000 years from a $\delta^{18} \mathrm{O}$ stalagmite record, Earth Planet. Sci. Lett., 235, 741-751, 2005.

Markel, E. R., Booth, R. K., and Qin, Y.: Testate amoebae and $\delta^{13} \mathrm{C}$ of Sphagnum as surface-moisture proxies in Alaskan peatlands, The Holocene, 20, 463-475, 2010.

Mauquoy, D. and van Geel, B.: Mire and peat macrofossils, Encyclopedia of Quaternary Science, Elsevier, Amsterdam, 23152336, 2007.

Mauquoy, D., Yeloff, D., van Geel, B., Charman, D. J., and Blundell, A.: Two decadally resolved records from north-west European peat bogs show rapid climate changes associated with solar variability during the mid-late Holocene, J. Quaternary Sci., 23, 745-763, 2008.

Ménot, G. and Burns, S. J.: Carbon isotopes in ombrogenic peat bog plants as climatic indicators: calibration from an altitudinal transect in Switzerland, Org. Geochem., 32, 233-245, 2001.

Moberg, A., Sonochkin, D. M., Holmgreen, K., Datsenko, N. M., and Karlén, W.: Highly variable Northern Hemisphere temperatures reconstructed from low- and high-resolution proxy data, Nature, 433, 613-617, 2005.

Moschen, R., Kühl, N., Rehberger, I., and Lücke, A.: Stable carbon and oxygen isotopes in sub-fossil Sphagnum: Assessment of their applicability for palaeoclimatology, Chem. Geol., 259, 262-272, 2009.

Naurzbaev, M. M., Vaganov, E. A., Sidorova, O. V., and Schweingruber, F. W.: Summer temperatures in eastern Taimyr inferred from a 2427-year late-Holocene tree-ring chronology and earlier floating series, The Holocene, 12, 727-736, 2002.

Nesje, A., Matthews, J. A., Dahl, S. O., Berrisford, M. S., and Andersson, C.: Holocene glacier fluctuations and winterprecipitation changes in the Jostedalsbreen region, western Norway, based on glaciolacustrine sediment records, The Holocene, 11, 267-280, 2001.

Nicolussi, K., Kaufmann, M., Melvin, T. M., van der Plicht, J., 
Schießling, P., and Thurner, A.: A 9111 year long conifer treering chronology for the European Alps: a base for environmental and climatic investigations, The Holocene, 19, 909-920, 2009.

Price, G. D., McKenzie, J. E, Pilcher, J. R., and Hoper, S. T.: Carbon-isotope variation in Sphagnum from hummock-hollow complexes: implications for Holocene climate reconstruction, The Holocene, 7, 229-233, 1997.

Proctor, M. C. F., Raven, J. A., and Rice, S. K.: Stable carbon isotope discrimination measurements in Sphagnum and other bryophytes: physiological and ecological implications, J. Bryol., 17, 193-202, 1992.

Reimer, P. J., Baillie, M. G. L., Bard, E., Bayliss, A., Beck, J. W., Bertrand, C. J. H., Blackwell, P. G., Buck, C. E., Burr, S. G., Cutler, K. B., Damon, P. E., Edwards, R. L., Fairbanks, R. G., Friedrich, M., Guilderson, T. P., Hogg, A. G., Hughen, K. A., Kromer, B., McCormac, F.-G., Manning, S. W., Ramsey, C. B., Reimer, R. W., Remmele, S., Southon, J. R., Stuiver, M., Talamo, S., Taylor, F. W., van der Plicht, J., and Weyhenmeyer, C. E.: IntCal04 Terrestrial radiocarbon age calibration, 26-0 ka BP, Radiocarbon, 46, 1029-1058, 2004.

Rice, S. K.: Variation in carbon isotope discrimination within and among Sphagnum species in a temperate wetland, Oecologia, 123, 1-8, 2000.

Rinne, K. T., Boettger, T., Loader, N. J., Robertson, I., Switsur, V. R., and Waterhouse, J. S.: On the purification of a-cellulose from resinous wood for stable isotope $(\mathrm{H}, \mathrm{C}$ and $\mathrm{O})$ analysis, Chem. Geol., 222, 75-82, 2005.

Robroek, B. J .M., Limpens, J., Breeuwer, A., and Schouten, M. G. C.: Effects of water level and temperature on performance of four Sphagnum mosses, Plant Ecol., 190, 97-107, 2007.

Schmidt-Vogt, H.: Die Fichte, Band 2, Teil 1: Wachstum, Züchtung, Boden, Umwelt, Holz, Parey, Hamburg, p. 563, 1986 (in German).

Schoning, K., Charman, D. J., and Wastegård, S.: Reconstructed water tables from two ombrotrophic mires eastern central Sweden compared with instrumental meteorological data, The Holocene, 15, 111-118, 2005.
Schwind, W.: Der Eifelwald im Wandel der Jahrhunderte ausgehend von Untersuchungen in der Vulkaneifel, Eifelverein, Düren, p. 340, 1984 (in German).

Skrzypek, G., Kalużny, A., Wojtuń, B., and Jȩdrysek, M.-O.: The carbon stable isotopic composition of mosses: A record of temperature variation, Org. Geochem., 38, 1770-1781, 2007.

Wacker, R.: Das Land an Mosel und Saar mit Eifel und Hunsrück, Spee, Trier, p. 567, 1991 (in German).

Wanner, H., Beer, J., Bütikofer, J., Crowley, T. J., Cubsch, U., Flückiger, J., Goosse, H., Grosjean, M., Joos, F., Kaplan, J. O., Küttel, M., Müller, S. A., Prentice, I. C., Solomina, O., Stocker, T. F., Tarasov, P., Wagner, M., and Widmann, M.: Mid-to Late Holocene climate change: an overview, Quaternary Sci. Rev., 27, 1791-1828, 2008.

Warner, B. G. and Charman. D. J.: Holocene soil moisture changes on a peatland in northwestern Ontario based on fossil testate amoebae (Protozoa) analysis, Boreas, 23, 270-279, 1994.

Wieder, K. K. and Vitt, D. H. (Eds.): Boreal peatland ecosystems, Springer, Berlin, p. 444, 2006.

Williams, T. G. and Flanagan, L. B.: Effect of changes in water content on photosynthesis, transpiration and discrimination against ${ }^{13} \mathrm{CO}_{2}$ and $\mathrm{C}^{18} \mathrm{O}^{16} \mathrm{O}$ in Pleurozium and Sphagnum, Oecologia, 108, 38-46, 1996.

Wissel, H., Mayr, C., and Lücke, A.: A new approach for the isolation of cellulose from aquatic plant tissue and freshwater sediments for stable isotope analysis, Org. Geochem., 39, 15451561, 2008.

Zanazzi, A. and Mora, G.: Paleoclimate implications of the relationship between oxygen isotope ratios of moss cellulose and source water in wetlands of Lake Superior, Chem. Geol., 222, 281-291, 2005 . 